\title{
Restorative Justice As One of the Methods of Disengagement from Terrorism in Indonesia
}

\author{
Sapto Priyanto, Mohammad Kemal Dermawan, and Arthur JS Runturambi1 \\ Criminology Department, Faculty of Social and Political Studies, University of Indonesia
}

Abstract

This paper explains about disengagement by using the concept of restorative justice to ex-convicts of terrorism and their networks in Indonesia. Restorative justice is carried out by voluntarily bringing together the terrorist bombing victims with ex-convicted terrorism cases and their networks in Indonesia. Focus group discussions are used in carrying out restorative justice thus ex-convicts of terrorism and their networks can be more open in issuing opinions. The findings in this study are the sincerity of terrorist bombing victims who have forgiven the ex-convicts of terrorism, even before the meeting, have made the ex-convicts of terrorism feel touched, cried and apologized for the actions of their friends and what they themselves have done. In addition, restorative

Corresponding Author:

Sapto Priyanto

saptopriyanto3792@gmail.com

Published: 11 November 2020

Publishing services provided by

Knowledge E

(c) Sapto Priyanto et al. This

article is distributed under the

terms of the

Attribution License, which

permits unrestricted use and

redistribution provided that the

original author and source are

credited.

Selection and Peer-review unde the responsibility of the IC-HEDS 2019 Conference Committee.

\section{G OPEN ACCESS} justice is not effective if it is carried out against former terrorism inmates from Poso, Central Sulawesi. Restorative justice can be one of the methods of disengagement for ex-convicted terrorists and their networks which will be effective in the future. Building a good relationship with former terrorism inmates and their networks need to be done before the implementation of restorative justice.

Keywords: Disengagement, Indonesia, Restorative Justice, Terrorism

\section{Introduction}

Acts of terrorism still occur in Indonesia until the end of 2019, namely by the occurrence of the suicide bomber who disguised himself as an online motorcycle taxi delivering food to Metropolitan Police of Medan, North Sumatra on November 13, 2019, which resulted in six people becoming victims [1]. This incident has made the deradicalization program which carried out by BNPT has become questionable. Bambang Rukminto stated that the concept of deradicalization which was made by the government (BNPT) was unclear because it did not define the word 'radical' strictly. In addition, BNPT does not have a database that can be used as a basis for assessing the success of the deradicalization program [2]. 
Disengagement is a part of the deradicalization activities which is carried out by BNPT. According to BNPT Deradicalization Director, disengagement is an activity: mentoring, coaching and empowering. Mentoring is carried out because the community needs to strengthen itself and the terrorists need to be heard. Coaching is done because BNPT should not lose in fostering terrorists compared to previous terrorist groups. Empowerment is done because most terrorists have problems with the economy. Deradicalization, besides it disengaged the old belief, it is also used as the new and moderate belief. The measurement of change to become moderate can be seen from the behavior, words, responses to the government, involvement in national day celebrations such as flag ceremonies, congregational prayers at the correctional institution mosque. The pinnacle of the scale of success is the change in the minds of the terrorists, which is not to make religion an ideology. Pancasila is the peak of all ideologies in Indonesia, if the terrorists are still hesitant in seeing Pancasila as the State ideology, it means that they are not yet being "pure", or not yet pure "deradicalized", they still have bargaining position.

Deradicalization approach is carried out with a religious and social approach; through the approach of community leaders and families, for there are terrorist inmates who do not want to change yet after being met with their families, they intend to change. The tools needed in deradicalization process is not physical support but the support from the community, budget support from the government, time support from implementers such as academics (lecturers) in order to obtain permission from their leaders for this project [3]. Based on the explanation from the BNPT Deradicalization Director, it is clear that Restorative Justice has not become an important method in dealing with terrorism in Indonesia.

\section{Methods and Conceptualization}

\subsection{Method}

Before carrying out restorative justice, the team prepared itself by holding 'trainer for trainer' training for all elements who would be involved in carrying out the activities, namely speakers who were victims of a terrorist bombing, Special Detachment 88 AT Indonesian Republic Police, the staff of the Ministry of Religion, and facilitators. The Purpose of the trainer for trainer training is to convey to all elements involved in the profile of former terrorism inmates and their networks, as well as the values that 
apply. While the Objective of the trainer for trainer training is that the implementation of restorative justice can be carried out successfully.

Former terrorism inmates and their networks who were willing to attend this activity had previously taken a preliminary survey which had done by the writer by visiting individuals and groups depending on their willingness to meet. So that all those present at restorative justice activities had stated that they were available voluntarily without any coercion from anyone.

Restorative in handling terrorists was carried out using the Focus group discussion (FGD) method. The FGD was chosen because there was equality among the participants present. FGD was conducted on former terrorism inmates and their networks in DKI Jakarta, West Java, Central Java, East Java, Central Sulawesi and Lampung from 20132015. The FGD speaker was Febby Firmansyah who was a victim of the Terrorist Bombing at the JW Marriot Hotel in 2002 who suffered 60\% burns.

FGD sessions always began with the facilitator opening the event with the introduction of all participants in the room and delivering the FGD topics that would take place, namely hospitality and testimony of victims of terrorist bombings. Furthermore, the speaker explained about his profile before becoming a victim of the terrorist bombing, the experience during the bombing, the process of healing wounds caused by the bomb, life with family and work today. In addition, the speaker also played a short film about the association of bombing victims and terrorism in Indonesia (ASKOBI Asosiasi Korban Bom Terorisme di Indonesia). After this session, the participants were asked to respond to the explanation of the speaker. The response of the participants who showed acceptance or rejection to the speaker can be seen from the attitude of the participants when the speaker delivered the material, and also from the responses of the participants to the material that had been submitted. The FGD is used to equalize participants with speakers, facilitators and stakeholders so that all present could freely express their responses. In the implementation of the FGD, the sitting position is made in a circle to show the equality between the speaker, facilitators, stakeholders and participants.

\subsection{Conceptualization}

\subsubsection{Terrorism}

Until now there has been no agreement on the definition of terrorism that can be used throughout the world. Middle East Countries Convention at 1979 defines terrorism 
(Kerstetter, 1983) as "Any act or threat of violence, whatever its motives or purposes, that occurs in advancement of an individual or collective criminal agenda and seeking to show panic among people, causing fear by harming them, or placing their lives, liberty or security in danger, or seeking to cause damage to the environment or to public or private installations or property or to occupying or seizing them, or seeking to jeopardize national resource" [4]

Some academics define terrorism as "a crime that has many faces" [5]; "acts of violence or threats to commit acts of violence aimed at random targets (there is no direct relationship with the perpetrators) which results in damage, death, fear, uncertainty and mass despair" [6]; "crimes against peace and security of mankind" [7]; "international or transnational crime" [8].

\subsubsection{Deradicalization and Disengagement}

The first thing that needs to be understood in deradicalization and disengagement is that individuals are involved in terrorism through a process. The process starts from joining terror groups, carrying out acts of terror, engaging in acts of terror, or eventually leaving or no longer involved in terrorism. [9]. Horgan \& Altier stated that deradicalization is an effort made to reduce the risk of recidivism, reduce one's involvement in the group, and change the recruitment narrative. Deradicalization includes all efforts to change the view that supports violence. In addition, the process of deradicalization begins when the inmate is in detention, to participate in some aftercare activities after release [10].

Horgan \& Altier define disengagement as the process of ceasing terrorist activity. It does not always involve a change in ideology or beliefs but does require an end to terrorist behaviors. Disengagement is distinct from the process of deradicalization, though they are sometimes related. Individuals may disengage from terrorism without necessarily 'de- radicalizing' and abandoning their violent ideology. Disengagement can be an individual or a collective process. The decision to disengage may be voluntary or involuntary. [11].

The term disengagement, as stipulated by Horgan [12] refers to "the process whereby an individual experiences a change in role or function that is usually associated with a reduction of violent participation". Horgan (2009) maintains that in disengaging an individual, it is equally important to "root the concept of deradicalization" to ensure that they are not at risk of re-pursuing violence as a means to an end.

Disengagement is conceptualized as a behavioral change. In disengagement, the individual desists from or reduces their use of violence while deradicalization seeks 
both behavioral and cognitive changes. Therefore, in deradicalization, the individual stops from using violence, and also moderates the extremist beliefs and attitudes which underpinned this use of violence [13].

\subsubsection{Restorative Justice}

The definition of restorative justice is very diverse. Johnstone and Van Ness explained that there are two categories of definitions of restorative justice, namely those based on the process of emphasizing the importance of meetings between stakeholders in crime and afterward, and those based on justice and emphasizing the results of restorative justice [14]. This definition also requires not only a restorative process but also interventions such as victim support,

In addition, according to the Association of Chief Police Officers of England, restorative justice focuses on victims of crime and non-crime. It also includes the violators of the law, both young people and adults, who are directly responsible to their victims and can be brought together in a facilitated meeting [15].

Restorative justice reappeared in the late 1970s as an alternative form of criminal justice practice, also served as an alternative sanction [16]. In the journal of Restorative Justice and Retributive Justice: An Opportunity for Cooperation or an Occasion Conflict in the Search for Justice, there is an explanation about the mediation process of perpetrators and victims which was carried out in North America, Canada in 1974. An officer, Mark Yantzi, took two prisoners to apologize to the victims from the damage caused by them [17].

Restorative justice, as happened in reconciliation in general, has been seen to apply to a variety of contexts where one party can be identified as a victim. Afterward, the victim and perpetrators of the reconciliation program are formed. The use of this process goes beyond the context of crime to domestic disputes and even international conflicts.

Restorative justice is very closely related to victims and perpetrators. In An Overview of Empirical Research on Restorative Justice Practices in Europe, it is explained that there are studies on victims' motivations in Belgium and the United Kingdom that show that they gain insight into action that will speed up the recovery of victims, which is dialogue or mediation to prevent repetition of crimes that have been done so that the community becomes safer. In addition, compensation is also an important factor for victims. Not because of the material but because of the victims need to be certain that the perpetrators are aware and truly admit their mistakes [18]. 
Some countries use the restoration process, namely, conferences, which are adapted from the practice of Maori tribe in New Zealand, where they carry out a mediation process that invites the main victims and the perpetrators, family members or friends of victims and perpetrators as well as representatives of the criminal justice system. Besides in New Zealand, this practice is also realized in Canada by the name of Circles. In this process, community members who are interested to participate are invited. The participants sat in a circle, with the discussion moving clockwise from person to person until the participants reached a resolution [19].

The presentation of Van Ness (2005) explained about several ways the perpetrators correct their mistakes, namely offering a sincere apology and regret for their behavior, then there is restitution where the offender pays the loss to the victim by providing services to the victim or the method agreed upon by the party related, and conduct community services by providing assistance to charities or governments.

Restorative justice values are grouped into two categories, which are normative values and operational values. Normative values in restorative justice are actively responsible, peaceful life, respect, and solidarity. The operational values are improving, mentoring, collaborating with related parties, empowerment, statements, meetings, moral education, protection, and resolution.

There are four biggest challenges to restorative justice related to definition, institutionalization, displacement, and relevance to practice. The problem of definition becomes an annoying problem, where restorative justice is now used in a variety of meanings, one of which is the recovery which is applied in various practices, namely improvement of the community, meeting victims and / or perpetrators, community services, and so forth.

The debate over the definition focuses on purists and maximalists, where puritans argue that restorative justice is a process that involves stakeholders to overcome the effects of crime while the maximalists argue that restorative justice is a choice that encourages improvements over the adverse effects caused by crime [20].

However, in time, the definitions become broader thus make the term meaningless. Restorative justice has become a 'brand' applied to every program and practice. This is not about the quality or effectiveness of a restorative justice program, but rather about the improvement of the concept of adjustment in its application. The future of restorative justice depends on the interaction between the parties that cause harm and those who are harmed.

There is also the problem of institutionalization which states that restorative justice initially focuses on developing practices that offer alternatives to formal criminal justice 
practices. Yet, it is different in practice, where most restorative justice programs have been institutionalized in the conventional criminal justice system, often combined with diversion practices or as alternative sanctions therein. Restorative justice approaches such as conferences tend to be viable choices only after the offender has been decided. The problem with this institutionalization is that the unclear translation of restorative justice has created confusion in its practice.

\section{Result}

Focus group discussions were conducted with former terrorist inmates and their networks in DKI Jakarta, Bandung West Java, Semarang Central Java, Surabaya East Java, Poso Central Sulawesi, and Lampung from 2013 to 2015.

TABLE 1: Participants FGD of Restorative Justice

\begin{tabular}{|c|c|c|c|c|}
\hline \multirow{2}{*}{ Year } & Location & $\begin{array}{c}\text { Former Terrorist } \\
\text { Perpetrator }\end{array}$ & Terrorist Network & Total (Person) \\
\hline \multirow{2}{*}{2013} & Jakarta & 4 & 7 & 11 \\
\cline { 2 - 5 } & Bandung & 2 & 8 & 10 \\
\hline \multirow{2}{*}{2014} & Semarang & 2 & 5 & 7 \\
\hline \multirow{2}{*}{2015} & Surabaya & 5 & 14 & 19 \\
\hline \multirow{2}{*}{ Total } & Poso & 8 & 0 & 10 \\
\hline
\end{tabular}

Sources: Post Prison Program Report 2013-2015 / created by Sapto Priyanto.

Overall, the restorative justice FGD that brought together Febby Firmansyah as the victim of the terrorist bombing at the JW Marriot Hotel in 2003 with former terrorism convicts around DKI Jakarta, Bandung West Java, Semarang Central Java, Surabaya and Lamongan East Java, Poso Central Sulawesi and Bandar Lampung has been done successfully. All former terrorist convicts and their networks did not come out of the room; they listened seriously to the victims' testimonies about the bombing. Most former terrorist convicts and their networks apologized to bombing victims on behalf of individuals and groups. Most former terrorism convicts and networks were aware that what they did was wrong and promised not to be involved in terrorism again. All former terrorist inmates and their networks supported the activity carried out by bombing victims, to be conducted sustainably so that it can prevent further acts of terrorism. The FGD did not get a response at the beginning in Poso, Central Sulawesi, because all participants thought they were not only perpetrators but also victims of the conflict, in 
which many of their families were killed at the beginning of the Poso conflict. However, after the FGD session, all ex-convicts wanted to talk to the victims and took a picture together.

\section{Discussion: Restorative Justice as Disengagement Method}

Restorative justice Implementation is a process, not an event. We must learn the scales of our practices deeply in order to do them well. Restorative Measures are a paradigmshifting away from punishment and external control to social engagement, repair damage, and community building [21]. Restorative justice (RJ) is a broad term that encompasses a growing social movement to institutionalize non-punitive, relationship-centered approaches for avoiding and addressing harm, responding to violations of legal and human rights, and collaboratively solving problems [22].

Restorative justice has been practiced so far in solving ordinary crime problems. Nevertheless, apparently in Indonesia, restorative justice can also be applied in disengagement activities for extraordinary crimes of terrorism. This is a phenomenon which according to the writer is a new thing.

Bringing victims together with perpetrators of crimes is not easy, especially for extraordinary crimes such as terrorism. The greatness and sincerity of victims in forgiving perpetrators is the main key to the success of restorative justice. This is what has happened in restorative justice for terrorism cases in Indonesia. The magnanimity of the victims of the JW Marriot Hotel in 2003, Febby Firmansyah, was the key to the successful implementation of restorative justice. Febby, despite experiencing difficult times in the process of healing from his burns, could bounce back in a short time to normal life because he realized what was happening to him was the will of Allah Subhanah Watta Allah (destiny), and because he got the full support from his family.

As stated by Van Ness, the facilitator was very instrumental in the process of restorative justice. Facilitators in restorative justice must really be able to understand the values that apply in terrorist groups and can bridge the communication process with victims and also other stakeholders such as religious leaders and police officers.

The form of restorative justice activities needs to be considered because if we directly focus on bringing the victims together with the perpetrators, the activity will not necessarily be successful. There are initial processes before the implementation of restorative justice prior to this activity. The core activity of restorative justice based on previous research was carried out in the form of a conference. This has been done 
by involving not only the facilitator, victims, and perpetrators of crime, but also other relevant stakeholders. The restorative justice activity that the writer used was the Focus Discussion Group (FGD) because the writer understood that most of the perpetrators would not like being advised or lectured by the interviewees for the mistakes they have made. In the FGD, all those present had the same or equal position. This was very influential in the implementation of restorative justice. The sitting position of all people present in restorative justice was made circular to show equality.

\section{Conclusion}

Based on the FGDs that have been carried out nine times, the writer can conclude that restorative justice as a method of disengagement for terrorism crimes in Indonesia has proven to be implemented well to former convicts of terrorism and their networks. It can be seen from the responses of the participants who mostly focused on listening to the explanation of the speakers, watched the profile film of the terrorist bombing victim's association in Indonesia and expressed their condolences over the suffering that was experienced by the speaker. The magnanimity of victims of terrorism is the key to the successful implementation of restorative justice. Restorative justice can be carried out even better if the speakers are direct victims of acts of terror committed by participants. Restorative justice is not optimal if the participants come from conflict areas such as Ambon and Poso, because they are also victims.

\section{References}

[1] Suryasumirat, A.R. (2019). 6 People Become Victims of Suicide Bombings in Mapolrestabes Medan. Liputan6.com, November 13, 2019.

[2] Rukminto, B. (2019). Terrorism Acts Still Occur, Deradicalization Program Failed? Tirto.id, November 14, 2019.

[3] Idris, I. (2019). Interview with Deputy Director of Deradicalization BNPT I.

[4] Kerstetter, W.A. (1983). Terrorism, Encyclopedia of Crime and Justice, in Sanford H Kadish (Editor in Chief), Vol 4. The Free Press: New York.

[5] Nitibaskara, R.R. (2002). Criminology Journal of Indonesia, Vol.2 No. III. December 2002.

[6] Mustofa, M. (2002). Criminology Journal of Indonesia, Vol.2 No. III. December 2002.

[7] Kusumah, W.M. (2002). Criminology Journal of Indonesia, Vol.2 No. III. December 2002. 
[8] Muladi. (2002). Criminology Journal of Indonesia, Vol.2 No. III. December 2002.

[9] Horgan, J. (2008). Deradicalization or Disengagement? A Process in Need of Clarity and a Counterterrorism Initiative in Need of Evaluation. Perspectives on Terrorism, 2(4), 3-8.

[10] Horgan, J.; Alitier, M.B. (2012). The Future of Terrorist De-Radicalization Programs. Conflict \& Security Journal. pp 84.

[11] Horgan, John; Alitier, M.B. (2012). The Future of Terrorist De-Radicalization Programs. Conflict \& Security Journal,pp 86.

[12] Horgan, J. (2009). Walking Away from Terrorism: Accounts of Disengagement from Radical and Extremist Movements. Routledge: New York. pp-152.

[13] Ferguson, N. (2016). Disengaging from Terrorism: A Northern Irish Experience, Journal for Deradicalization. pp-2.

[14] Van Ness, D.W. (2005). An Overview of Restorative Justice around the World. Centre for Justice \& Reconciliation Prison Fellowship International. pp-4.

[15] Shewan, ACC G. (2011). Restorative Justice Guidance and Minimums Standards. Association of Chief Police Officers of England.

[16] Wood, W.; Suzuki, M. (2016). Four Challenges in the Future of Restorative Justice. Victim \& Offenders. pp-1-24

[17] Hermann, D.H.J. (2017). Restorative Justice and Retributive Justice: An Opportunity for Cooperation or an Occasion for Conflict in the Search for Justice. Seattle Journal for Social Justice, Issue 1.

[18] EFRJ. (2017). Effectiveness of Restorative Justice Practices: An Overview of Empirical Research on Restorative Justice Practices in Europe.

[19] Van Ness, D.W. (2005). An Overview of Restorative Justice Around the World. Centre for Justice \& Reconciliation Prison Fellowship International. pp-4.

[20] Wood, W., Suzuki, M. (2016). Four Challenges in the Future of Restorative Justice. Victim \& Offenders. pp-3-5.

[21] Riestenberg, N. (2015). The Restorative Implementation: Paradigms and Practices. Restorative Practices in action Journal: for School and Justice Practitioners. New York State Permanent Judicial Commission on Justice for Children

[22] Fronius, T. et.al. (2019). Restorative Justice in U.S. Schools: an Updated Research Review. The WestEd Justice \& Prevention Research Center. 